\author{
St ud i P hilos o phic a \\ Wratis l a vi e n s i a \\ vol. XIV, fasc. 3 (2019) \\ DOI: $10.19195 / 1895-8001.14 .3 .3$
}

\author{
JAN KRASICKI \\ ORCID: 0000-0003-2700-7715 \\ Uniwersytet Wrocławski
}

\title{
Hermann Cohen i Drugi. Triumf i upadek ,czystego rozumu”
}

\section{Hermann Cohen and the Other: The Triumph and Fall of "Pure Reason"}

\begin{abstract}
The article poses the question of the contemporary validity and meaning of Hermann Cohen's philosophical thought. It is argued that in order to understand its phenomenon one has to go beyond the epistemological and methodological perspectives in which Cohen's work has usually been analyzed and probe into the philosopher's deepest spiritual and intellectual formation - that of Judaism. The author claims that Cohen, otherwise a celebrated academic scholar, was first of all a rabbi, i.e. a teacher in the Judaist tradition. This is the context in which we can weigh his friendship with young Franz Rosenzweig - it was Rosenzweig who first recognized the revolutionary significance of Cohen's philosophy of religion and utilized the latter in his seminal work The Star of Redemption (Der Stern der Erlösung) where he emphasized the late stage of Cohen's intellectual evolution, especially the one associated with Religion der Vernunft aus den Quellen des Judentums (1919). This book is viewed as essentially a reinterpretation of Kant's moral theory and philosophy of religion in terms of Judaism and the Bible, which in itself marks Cohen's departure from critical idealism and his shift towards the dialogic philosophy. In this context one can see Cohen as a teacher of the German nation, someone who could accurately examine the dangers of the Romantic theory of
\end{abstract}

\footnotetext{
* Rozszerzona i zmieniona wersja artykułu: J. Krasicki, Gierman Kogien i problema Drugogo. Torżestwo i padienije „czistogo razuma”, „Terra Aestheticae. Tieoreticzeskij żurnał Rossijskogo estieticzeskogo obszczestwa" nr 2 (2) 2018; J. Krasicki, Hermann Cohen and the Other. The Triumph and Fall of „Pure Reason”, „Terra Aestheticae. Journal of Russian Society for Aesthetics” 2 (2) 2018.
} 
the nation as well as the Romantic (especially Fichtean) version of Kant's moral theory, dangers corroborated by 20th-century history. While stressing Cohen's positive contribution to our understanding of the contemporary world, it should be added that the philosopher's belief in the liberating potential of "pure reason" was heavily damaged in the face of the totalitarian ideas in modern Europe. It does not mean, however, that his thought has lost its potency. On the contrary, in the age of the crisis of rationality Cohen's work may be seen as a vital testament. Its effectiveness, though, lies not in the power of "pure reason" but in the power of dialogue and the imperative to love one's neighbor, a rational and free act which surpasses all religious and speculative constraints. Accordingly, the article concludes by pointing to the timeliness and validity of Cohen's spiritual and intellectual legacy.

Keywords: Neo-Kantianism, Judaism, the Other, dialogue, Nazism, "pure reason"

\section{Hermann Cohen - myśliciel aktualny?}

Hermann Cohen staje się myślicielem ,aktualnym”1. Rosyjska badaczka Zinaida A. Sokuler słusznie łacczy jego postać z procesem odrodzenia ontologii lat dwudziestych ubiegłego wieku w Niemczech, a także powstaniem filozofii dialogu². Podkreślając rolę Cohena w ,zwrocie ontologicznym” i filozofii dialogu ${ }^{3}$, jednocześnie przyznaje, że niestety zarówno w rosyjskiej, jak i w zachodniej literaturze dominuje obraz Cohena, jako „sprowadzającego całą filozofię do teorii wiedzy naukowej”, któremu nieustannie zarzucano „metodologizm i gnozeologizm”4. Po tym jak z jednej strony neokantyzm, którego był jednym z głównych przedstawicieli, został prawie zesłany do archiwum filozofii ${ }^{5}$, a z drugiej — w sytuacji powrotu do dialogicznego dziedzictwa filozofii Cohena, pytanie o ,aktualność” marburskiego filozofa znowu staje się ważne w kontekście dziejowych i totalitarnych doświadczeń ubiegłego wieku.

Rozważając powody tego wzrastającego zainteresowania dorobkiem myślowym marburskiego myśliciela, naszym zdaniem, w tej kwestii byłoby jednak przedsięwzięciem chybionym bronić stanowiska, że współczesna „aktualność” Cohena polega na renesansie jego epistemologii. Trudno bronić takiego stanowiska, mając na uwadze takie ideowe procesy i wydarzenia w myśli XX wieku, jak współczesna Cohenowi

${ }^{1}$ Z.A. Sokuler, Gierman Kogien kak aktualnyj myslitiel. Razmyszlaja nad knigoj: Kogien G. Tieorija opyta Kanta, https://www.google.com/url?sa=t\&rct=j\&q=\&esrc=s\&source=web\&cd=4\&ca $\mathrm{d}=$ rja\&uact $=8 \&$ ved $=2$ ahUKEwiD84zUqd3cAhUHL1AKHSTjCKQQFjADegQIBxAB\&url $=$ http $\% 3$ A\%2F\%2Fplatona.net\%2Fload\%2Fzhurnaly_po_filosofii\%2Fvoprosy_filosofii\%2Fvoprosy_filosofii_2013_g_1\%2F78-1-0-3942\&usg=AOvVaw2kZTÜRUhbJt_sv0hS-owA_(dostęp: 7.08.2018).

2 Z.A. Sokuler, Gierman Kogien i fiłosofija dialoga, Moskwa 2008, s. 45.

3 Ibidem.

${ }^{4}$ Ibidem [cytaty, jeśli nie zaznaczono inaczej, w tłumaczeniu autora].

5 Jak piszą rosyjscy badacze, neokantyzm uważano za „zjawisko całkowicie marginalne”, niegodne poważnego historyczno-filozoficznego traktowania, a krytyczna naukowa ocena tego kierunku miała miejsce niedawno (lata osiemdziesiąte XX wieku). Por. K. Krajnien, W.N. Biełow, Izuczenije nieokantianstwa: ukazanija $k$ cztieniju, „Kantowski sbornik. Naucznyj żurnał” (28) 2 (2008), s. 66-67. 
krytyka idealizmu, transcendentalizmu i krytycznej filozofii w filozofii europejskiej oraz rosyjskiej, na przykład Mikołaja Bierdiajewa ${ }^{6}$, znany „spór” między Heideggerem a Cassirerem w Davos w 1929 roku ${ }^{7}$, nie mówiąc już o nowoczesnej i różnorodnej „detranscendentalizacji” tak zwanego czystego rozumu, jego stałej transformacji w rozum „usytuowany”, a także jego postępującej, dyktowanej przez badania w obrębie medycyny, neurobiologii, psychologii percepcji, kognitywistyki itd. transformacji w rozum „wcielony"'. Po krytyce dualizmu Kartezjańskiego dokonanej przez takich współczesnych fenomenologów jak Michel Henry czy Maurice Merleau-Ponty, a dalej wykazaniu „błędu Kartezjusza” (Descartes' Error) ${ }^{10}$ przez neurobiologów, na przykład António Damásio, padają ostatnie bastiony „czystego rozumu” i transcendentalizmu. W końcu wydaje się to przedsięwzięciem mało realnym po krytyce poznania dokonanej w pracach Michela Foucaulta i aby kwestię skonkludować, posługując się postmodernistycznym językiem, po nowoczesnej dekonstrukcji „czystego rozumu”11.

\section{Fenomen Cohena i fenomen judaizmu}

Aby zrozumieć fenomen Cohena, jak nam się wydaje, należy spojrzeć na jego osobowość i ideową genealogię w nieco głębszym i szerszym kontekście, niż jest to

${ }^{6}$ Zob. J. Krasicki, Bierdiajew a neokantyzm, [w:] idem, Bierdiajew i inni. W kręgu myśli rosyjskiego renesansu religijno-filozoficznego, Warszawa 2012, s. 133 n. Jak pisze rosyjska badaczka N. Dmitrijewa, w rosyjskiej recepcji neokantyzmu dominowały dwa podejścia. Pierwsze bardziej krytyczne właściwe dla „szkoły moskiewskiej” wynikające w dużej mierze z nieznajomości pism neokantystów (braku tekstów $\mathrm{w}$ oryginale), ale także wynikające $\mathrm{z}$ tkwienia w tradycyjnym sposobie uprawiania filozofii, pozostawania w modelach tradycyjnej metafizyki. Tak było na przykład w przypadku J. Trubieckiego i innych przedstawicieli — ufundowanej jeszcze przez W. Sołowjowa — „moskiewskiej szkoły” metafizyki Wszechjedności. Dużo bardziej otwarte i życzliwe wobec zasad nowej filozofii podejście cechowało reprezentantów „,szkoły petersburskiej”, na Uniwersytecie w Sankt-Petersburgu działali wszak akademiccy neokantyści z A.I. Wwiedeńskim na czele. Recepcja neokantyzmu miała także swoją wersję polityczną, podyktowaną przez sytuację polityczną w Rosji, w której większą rolę od filozoficznych odgrywały czynniki ideologiczne a negatywny stosunek do rosyjskiego neokantyzmu ,z lewa" — jak pisze rosyjska badaczka — był, oczywiście, wynikiem rewizji marksizmu, jaką na gruncie neokantyzmu przeprowadzili E. Bernstein i K. Kautski. Bierdiajew, jak inni ,legalni marksiści”, choć stał na ideowo przeciwnym biegunie niż marksistowscy ortodoksi (na przykład Lenin) „był jednym z pierwszych, który rozpoczął ataki na neokantyzm”, choć rzecz jasna z innych ideowych pozycji, jako że w momencie włączenia się w polemikę z neokantyzmem Bierdiajew przesunął się już z pozycji ,legalnego marksizmu” (czyli, mimo wszystko filozoficznej „lewicy”) w kierunku „prawym” i podobnie jak np. S.N. Bułgakow stał już na stanowisku idealizmu. Zob. N.A. Dmitrijewa, Russkoje nieokantianstwo: „Marburg w Rossii”, Moskwa 2007, s. 220-223. Zob. także B. Czardybon, Rosyjski wariant kantyzmu i neokantyzmu, „Estetyka i Krytyka” (26) 3 (2012) (Postneokantyzm-ontologizm).

7 Z.A. Sokuler, Gierman Kogien i fitosofija dialoga, s. 45-46.

${ }^{8}$ J. Habermas, Działanie komunikacyjne i rozum zdetranscendentalizowany, [w:] idem, Między naturalizmem a religia. Rozprawy filozoficzne, tłum. M. Pańkow, Warszawa 2012, s. 26.

${ }^{9}$ Jak pisze neurobiolog i neurolog A. Damasio: „Istnienie umysłu jest nie do pomyślenia, jeśli nie będzie on w jakiś sposób wcielony" i w uzasadnieniu tej tezy przywołuje własną praktykę lekarską oraz analizuje ogromny materiał badawczy z zakresu neurobiologii i neurologii. Jego zdaniem tu tkwi istota „błędu Kartezjusza”, nie istnieje umysł niecielesny, separowany od ciała. Zob. A. Damasio, Błąd Kartezjusza. Emocje, rozum i ludzki mózg, tłum. M. Karpiński, Poznań 2016, s. 272-277.

10 Ibidem.

11 R. Rorty, Przygodność, ironia, solidarność, tłum. W.J. Popowski, Warszawa 2009, s. 174. 
zwykle przyjęte w literaturze przedmiotu, to znaczy popatrzeć na jego postać nie tylko jako na uczonego, filozofa, profesora uniwersytetu w Marburgu, ale spróbować dotrzeć do wewnętrznych korzeni jego tożsamości nie tylko intelektualnej, lecz także duchowej. Korzenie te tkwią w religii, z której wywodzi się duchowa formacja filozofa i w tradycji w której dorastał, czyli w judaizmie (pełne nazwisko filozofa to Hermann Jecheskel Cohen). Pozwala to dostrzec, że fenomen Cohena i fenomen judaizmu są nierozdzielne. Tajemnica Cohena, zwłaszcza ostatnich lat jego życia, w tej mierze rozpoczętych w 1912 roku wykładów w berlińskim Lehranstalt für die Wissenschaft des Judentums (Instytut Nauki Żydowskiej) ${ }^{12}$, i ostatniej opublikowanej w 1919 roku, już po śmierci filozofa, pracy z filozofii religii Religion der Vernunft aus den Quellen des Judentums, zawarta jest w religii jego dzieciństwa i młodości — w judaizmie. Cohen rozpoczął swoją drogę życiową jako wyznawca judaizmu i skończył jako wyznawca judaizmu. Tajemnica końca jego drogi zawiera się w jej początku.

W rezultacie należy stwierdzić, że istota współczesnego renesansu myśli Cohena wydaje się polegać na czymś zupełnie innym niż jego twórczy wkład w powstanie marburskiej szkoły neokantyzmu ${ }^{13}$ oraz rozwój nauki Kanta. Rok 1912, w którym Cohen opuścił Marburg i osiedlił się w Berlinie, podejmując jednocześnie wykłady w Instytucie Nauki Żydowskiej, przyjmuje się za umowny koniec tak zwanej marburskiej szkoły neokantyzmu. Jednak datę tę można również przyjąć za umowny początek nowej drogi żydowskiego myśliciela, wraz z którą rozpoczął nowy etap nie tylko własnej filozofii, lecz także filozofii ,nowego myślenia”14. Krokiem tym Cohen rozpoczął filozoficzny trakt, którym podążyli potem inni filozofowie dialogicy i na którym bez niego najbardziej znany z uczniów Cohena, Franz Rosenzweig ze swoją Gwiazda zbawienia (Der Stern der Erlösung), nigdy by się nie znalazł.

W tym kontekście, czyli w kontekście tradycji judaizmu, należy także rozpatrywać intelektualną i duchową więź, jaka zawiązała się między Cohenem i Rosenzweigiem. Spotkanie dwudziestopięcioletniego Rosenzweiga z siedemdziesięcioletnim Cohenem w berlińskim Instytucie Nauki Żydowskiej było bowiem nie tylko spotkaniem dwóch filozofów — pierwszego, stojącego u początku swojej naukowej drogi i drugiego, stojącego u jej końca. Było spotkaniem człowieka poszukującego nie tylko wiedzy, lecz także zbawienia, a jeśli wiedzy, to prowadzącej do zbawienia; spotkaniem nie tylko z filozofem, lecz także z mędrcem, biblijnym ,prorokiem”

12 M. Ciszewski, Cohen Hermann, [w:] Encyklopedia Katolicka, t. 3, R. Łukaszyk, L. Bieńkowski, F. Gryglewicz (red.), Lublin 1985, s. 536.

13 Zob. np. W. Tatarkiewicz, Szkoła marburska i jej idealizm (w setną rocznicę marburskiej dysertacji Władysława Tatarkiewicza), P. Parszutowicz (red.), Kęty 2010.

${ }^{14}$ F. Rosenzweig, Nowe myślenie. Kilka uwag ex post do Gwiazdy zbawienia, [w:] idem, Gwiazda zbawienia, tłum. T. Gadacz, Kraków 1998, s. 659-689.

15 Zob. A.J. Heschel, Prorocy, tłum. A. Gorzkowski, Kraków 2014. Taka wedle rosyjskiego znawcy filozofii Cohena była jego zasadnicza filozoficzna postawa. „Całym swoim życiem i twórczością — pisze on - Cohen uzasadnia konieczność filozofii, dąży do tego aby była proroczą i aby filozof był prorokiem. Tylko poprzez taki ideał może zostać obroniona (оправдана) kulturowo- historyczna misja filozofa. Dlatego Platon powinien zostać zjednoczony z Izajaszem. W ten sposób filozofia objawia swoją systematyczną doskonałość w historycznym procesie swego stanowienia się i rozwoju, a judaizm niezależnie od swego religijnego ekskluzywizmu (исключительносъ) zyskuje wymiar ogólnokulturowy przygoto- 
Wskazuje na to już sam tytuł głównego dzieła Rosenzweiga, w rzeczywistości jedynego wielkiego dzieła jego krótkiego życia ${ }^{16}$, dzięki któremu stał się znany w filozoficznym świecie. Nazwa Gwiazda zbawienia (staro-hebr. Magen Dawid) nie jest przypadkowa, wybrana została przez niego rozmyślnie i świadomie w opozycji do filozoficznych kategorii Hegla. Jego droga myślowa wiedzie bowiem od krytyki oceny Heglowskiej koncepcji dialektycznego „zniesienia” (Aufhebung) do dialogu; od Heglowskiej „triady” do „Gwiazdy Dawida”17. Na eksplikacji znaku „Gwiazdy Dawida" opiera się także cała ideowa struktura tego dzieła, pozostajacc w jawnej opozycji wobec Heglowskiej ontologii Wszystkiego ( $A l l)$.

Zwraca się uwagę na to, że Cohen był twórczym kontynuatorem myśli Kanta, wybitnym matematykiem, logikiem i metodologiem i w tym sensie pisze się, że jego słuchacze, zarówno w Marburgu, jak i w Berlinie, byli wprost zdumieni „precyzją” jego wywodów i rozumowań ${ }^{18}$. To prawda, jednak jeśli chcemy odpowiedzieć sobie na pytanie o to, dlaczego uczony tak mocno wpłynął na młodego Rosenzweiga, musimy zwrócić uwagę, że w istocie tajemnica jego wpływu na Rosenzweiga leży nie tyle w logice i „precyzji” jego myśli, ile w jego niezwykłej „proroczej” i charyzmatycznej osobowości.

Przemawiają za tym świadectwa słuchaczy jego wykładów oraz osób, które miały bezpośredni kontakt z Cohenem. Tak więc, jak wspomina w swojej książce poświęconej stosunkom Niemców i Żydów Gershom Scholem, Cohen, ten pierwszy żydowski filozof, który zrobił akademicką karierę na niemieckim uniwersytecie, przychodził do swoich słuchaczy i studentów nie tylko jako współczesny uczony, lecz także jako ktoś z czasów dawnych biblijnych proroków. Jako „szlachetny" w sensie kabały luriańskiej (szlachetny — hebr. acil) ${ }^{19}$. „» Szlachetna « postać Cohena — pisze Scholem — jakby przywędrowała do nas z czasów starożytnych (my wszyscy, którzy siedzieliśmy jeszcze u jego stóp, tak to odczuwaliśmy" ${ }^{\prime 20}$. Podobnie był przyjmowany Cohen podczas swojej wizyty w Rosji w 1914 roku $^{21}$.

wując ogólnoludzki związek państw (всечеловеческий государственный союз)". W.N. Biełow, Fiłosofija rieligii Giermana Kogiena, [w:] Poznanije i rieligija. Epistiemołogija rieligioznogo opyta w russkoj i jewriejskoj mysli, J. Dobieszewski, S. Krajewski, J. Mach (red.), Warszawa 2018, s. 229.

${ }^{16} \mathrm{~W} 1922$ roku w wieku 36 lat Rosenzweig zachorował na ciężki paraliż (Amyotrophen Lateralsklerose), który doprowadził go do niemal całkowitego unieruchomienia i utraty mowy, ale nie pozbawił funkcji intelektualnych (filozof dyktował żonie swoje myśli). Po długich cierpieniach umiera w 1929 roku. Przed śmiercią pisze z trudem recenzję książki Cohena Religion der Vernunft aus den Quellen des Judentums (1919). Zob. A. Serafin, Cohen - Rosenzweig - Heidegger. O zmianie frontu w Davos, „Estetyka i Krytyka” 26 (3) 2012 (Postneokantyzm-ontologizm), s. 161 n.

17 Z.A. Sokuler, Gierman Kogien i fitosofija dialoga..., s. 134 n.

${ }^{18}$ G. Scholem, Żydzi i Niemcy, Eseje. Listy. Rozmowa, tłum. A. Zawanowska, A. Lipszyc, Sejny 2006, s. 177.

19 Ibidem, s. 197, przypis 5.

${ }^{20}$ Ibidem.

21 ,»Cohen przyjechał do Rosji na zaproszenie Żydowskiego Stowarzyszenia Popierania Nauki nie jako czołowy przedstawiciel filozofii niemieckiej i neokantyzmu marburskiego «, lecz jako »jeden z najciekawszych przedstawicieli zachodniego żydostwa«, »sędziwy żydowski myśliciel « po to, aby »pocieszyć i dodać otuchy słabym na duchu braciom swoim, braciom z wiary i krwi«. Wygłosił tutaj dwa wykłady - Moralna treść religii żydowskiej oraz Istota religii żydowskiej. Cel wizyty i jej narodowo-filozoficzny podtekst były podyktowane głównie tym, że miał on [Cohen - B.C.] słaby oddźwięk społeczny. 


\section{Cohen, Rosenzweig i „nauka"}

Współczesny włoski filozof Giorgio Agamben ${ }^{22}$ pisze, że w judaizmie istnieje nieznany $\mathrm{w}$ innych religijnych tradycjach stosunek do nauki; w judaizmie nauka, niezależnie od jej celu edukacyjnego, zawsze ma cel religijny i mesjański.

Włoski intelektualista ilustruje ten fakt spektakularnym wydarzeniem z historii Izraela. Tak więc, gdy w 70 roku legiony rzymskie po raz drugi zniszczyły Świątynię Jerozolimską, Hannah ben-Zakkaj, rabin, który potajemnie uciekł z oblężonej Jerozolimy, wyjednał u cesarza Wespazjana (cesarz Wespazjan prowadził wojnę żydowską w latach 66-70) zgodę na dalsze studia w mieście Jamnia. I choć Świątynia Jerozolimska nie została już nigdy odbudowana, to „nauka”, czyli „Talmud”, stała się prawdziwą świątynią Izraela. W judaizmie, jak pisze Agamben, uczony doświadcza szacunku nieznanego we wszystkich innych tradycjach, albowiem staje się świadkiem wartości mesjanistycznych, nieznanych w świecie pogańskim, a w jego postawie nie tyle chodzi o naukę, ile o ,zbawienie"23.

Dla zrozumienia fenomenu Cohena ta mesjanistyczna cecha judaizmu jest bardzo ważna. Agambenowskiej charakterystyki roli uczonego i nauki w judaizmie nie można wprawdzie przypisać bezpośrednio do postaci Cohena, który choć tylko rozpoczął studia w seminarium rabinackim we Wrocławiu, aby w 1861 roku przenieść się na wydział filozoficzny Uniwersytetu Wrocławskiego, a dalej Uniwersytetu Berlińskiego, jednak wewnętrznie, duchowo pozostał do końca swoich dni, pomimo swojej dalszej kariery akademickiej, żydowskim rabinem, „nauczycielem”, do którego zwraca się nie tylko po wiedzę, lecz także po poradę w ważnych i decydujących sprawach życia, a jeśli po wiedzę to wiedzę mesjańską, zbawiającą.

W tym znanym z tradycji religijnej judaizmu i rabinizmu znaczeniu stał się on rabbi, „nauczycielem”, „mistrzem” także dla Rosenzweiga ${ }^{24}$, dziedzictwo to widać w postawie jego ucznia. Zbawienie ludzkiej jednostki, a nie tylko spekulacyjne rozumowania, stanowi główny i ostateczny cel pracy autora Gwiazdy zbawienia, jednego z pierwszych Żydów powracających do mesjańskiej wiary swoich ojców (baa-lej-tituwa $)^{25}, \mathrm{w}$ imię której w książce tej wystąpił z taką gorliwością i zapałem przeciwko pseudo-mesjańskiej idei zbawienia Hegla (Versöhnung), jako „pojednania wszystkiego we Wszystkim”. Uczynił to Rosenzweig w rozprawie zaczynającej się od słów skierowanych przeciwko filozofii, która widzi „Wszystko” (niem. All), a jednocześnie nie jest w stanie zobaczyć tego, co rzeczywiste, czyli niepowtarzal-

Cohen przyjechał do Rosji 22 kwietnia 1914 r. i do 28 kwietnia wygłosił dwa wykłady w Petersburgu, potem były dwa wykłady w Moskwie, 5 maja wykładał w Rydze, 10 maja — w Wilnie, 14 maja w Warszawie. W rosyjskich miastach Cohena witali tacy znani rosyjscy filozofowie, jak: S.N. Bułgakow, N.O. Łosski, F.A. Stiepun, B.W. Jakowienko, W.E. Sezeman i in.": B. Czardybon, Rosyjski wariant kantyzmu i neokantyzmu, s. 251, przypis 71. Badaczka cytuje pracę W.N. Biełow, Uczenije Giermana Kogiena w Rossii: osobiennosti riecepcyi, [w:] Nieokantianstwo niemieckoje i russkoje: mieżdu tieorijej poznanija i kritikoj kultury, I.N. Grifcowa, N.A. Dmitrijewa (red.), Moskwa 2010.

${ }^{22}$ G. Agamben, Idea nauki, [w:] idem, Idea prozy, tłum. E. Górniak Morgan, Warszawa 2018, s. 59-60.

${ }^{23}$ Ibidem, s. 60.

${ }^{24}$ J. Krasicki, „Ot smierti, ot triepieta pieried smiertiu...” (Kogien - Rozienzwajg - Chajdieggier), [w:] idem, Razum i Drugoj. Opyty po russkoj i jewropiejskoj mysli..., s. 247-249.

${ }^{25}$ Por. F. Rozienzwajg, Zwiozda izbawlienija, pier. s niem. jaz. J. Jandutowoj, Moskwa 2017. 
nej ludzkiej jednostki, egzystencji. Zdaniem Rosenzweiga filozofia nie zaczyna się od poznania „Wszystkiego”, ale „od śmierci, od trwogi śmierci zaczyna się wszelkie poznanie Wszystkiego"26. „We Wszystkim” nie ma nic rzeczywistego — ani rzeczywistego życia, ani rzeczywistej śmierci — i jak powiada z przekąsem: „Wszystko nie umiera i nic nie umiera we Wszystkim"27.

\section{Cohen i ,zmiana pozycji”" (Vertauschte-Fronten)}

W tym kontekście staje się bardziej zrozumiała nie tylko dokonana przez Rosenzweiga po debacie w Davos (1929), ,zmiana frontów” (Vertauschte-Fronten), lecz także mesjanistyczny charakter jego filozofii, zbieżny z mesjanistycznym przesłaniem filozofii Cohena i z mesjanizmem żydowskiej filozofii, począwszy od przedstawicieli żydowskiego oświecenia (haskala) Mojżesza Mendelssohna i Gottholda E. Lessinga, po mesjanizm żydowskich filozofów XX wieku - Waltera Benjamina, Martina Bubera i Emmanuela Lévinasa ${ }^{28}$.

Nie sposób przy tym nie zauważyć, że ta „zmiana frontów" w biografii Rosenzweiga ma rangę symbolu. „Zmiana frontów” to nie tylko recenzja z ostatniego dzieła Cohena, lecz także filozoficzne credo dalszej drogi jego ucznia. Pisał on w niej:

Niedobitki ,szkoły" - nie Cassirer — chciałyby z martwego mistrza zrobić swojego mistrza. Lecz żywa, krocząca naprzód historia ducha udaremnia wszelkie takie szkolne przedsięwzięcia. Nie baczy na tego rodzaju roszczenia i teraz, gdy martwy Cyd ponownie wyjeżdża na koniu, zmienia ona fronty. Szkoła wraz z mistrzem szkoły umiera. Wszakże sam mistrz żyje nadal ${ }^{29}$.

Dokonana przez Rosenzweiga „zmiana frontów” to zatem nie tylko jeden z objawów jego odejścia od tradycji neokantyzmu, lecz także pożegnanie z całą tradycją niemieckiego idealizmu, którego uosobieniem była dla niego filozofia Hegla. Drogi, która rozpoczęła się w 1912 roku od krytyki myśli autora Fenomenologii ducha w pracy doktorskiej Rosenzweiga Hegel $i$ państwo (Hegel und der Staat, 1920) i została doprowadzona do swych ideowych konsekwencji w Gwieździe zbawienia. Pracy, w której w monizmie Heglowskiej myśli i w ogóle niemieckiej Identitätsphilosophie proroczo przewidział początki tych destruktywnych ideologicznych trendów, które z całą mocą ujawniły się w totalitarnych ideologiach ubiegłego stulecia, w ich strachu przed Innym, Drugim ${ }^{30}$.

Mając na uwadze ideową drogę Rosenzweiga, trzeba powiedzieć, że to Cohen wprowadził go na ścieżkę filozoficzną, którą podążyli potem inni filozofowie dia-

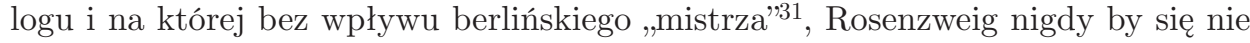

${ }^{26}$ F. Rosenzweig, Gwiazda zbawienia, s. 51.

27 Ibidem, s. 53.

28 Z.A. Sokuler, Gierman Kogien i fitosofija dialoga..., s. 200 n.

${ }^{29}$ F. Rosenzweig, Zmiana frontów, tłum. A. Serafin, „Kronos” 2 (2012), s. 123.

30 J. Krasicki, Inny i śmierć Innego w filozofii G.W.F. Hegla i Franza Rosenzweiga, [w:] Bóg - człowiek - świat: szkice w myśli filozoficznej Franza Rosenzweiga, D. Jacyk-Manikowska (red.), Wrocław 2017 , s. $105-144$.

31 J. Krasicki, „Ot smierti, ot triepieta pieried smiertiu...” (Kogien - Rozienzwajg - Chajdieggier)..., s. 247 . 
znalazł. Ale jednocześnie nie ulega wątpliwości to, że zasługa Rosenzweiga leży nie tylko w wydaniu opublikowanej już po śmierci Cohena pracy z filozofii religii, ale w czymś znacznie bardziej doniosłym, w tym, że to właśnie Rosenzweig uwolnił dziedzictwo Cohena z idealistycznych ograniczeń. Można także domniemywać, że gdyby nie jego działalność w tym zakresie w dużej mierze dzieło to podzieliłoby los neokantyzmu, stanowiącego dzisiaj, jak już pisaliśmy, w znacznej części ,archiwum filozofii", a nie jak to ma miejsce obecnie źródło żywej filozoficznej inspiracji.

\section{Dialogizm Cohena}

Dialogizm Cohena organicznie wyrasta z duchowej formacji filozofa, wynika z jego judaizmu, który jest sensu stricte religią dialogiczną. W tym sensie można powiedzieć, że ze względu na swój judaizm Cohen urodził się dialogikiem, a filozofem dopiero się stał.

Dlatego ma rację polski badacz Wojciech Hanuszkiewicz, kiedy porównując między sobą dwie prace Cohena, dzieło Religion der Vernunft aus den Quellen des Judentums oraz System der Philosophie, będący przedstawieniem systemu krytycznego idealizmu, twierdzi, że Cohen najpierw był „filozofem dialogu”, a dopiero potem „krytycznym idealistą"32. Przemawia za tym to, że jak pisze Hanuszkiewicz, pierwsza wersja dzieła z filozofii religii (artykuł) została opublikowana już w 1900 roku, czyli dwa lata wcześniej niż System der Philosophie (publikacja: 1902 pierwsza część, 1907 - druga część, 1912 - trzecia część) $)^{33}$. Ta pierwsza wersja została opublikowana jako artykuł Liebe und Gerechtigkeit in den Begriffen Gott und Mensch ${ }^{34}$. Dlatego też mając na myśli judaizm Cohena, można zaryzykować stwierdzenie, że Cohen jako wyznawca judaizmu dialogikiem był zawsze, a ,krytycznym idealistą" czy wręcz filozofem stał się dopiero dzięki swojej intelektualnej formacji. Był bowiem wyznawcą religii dialogicznej, w której Inny, Drugi jest fundamentem, podczas kiedy ambicją filozofii niemieckiej po Kancie stało się dążenie do zniesienia „resztek materializmu” (M. Zdziechowski) w postaci „rzeczy samej w sobie" (Ding an sich) w systemie absolutnego idealizmu Johanna F. Fichtego, a w końcu zrównania transcendentalnego Ja z Bogiem i „zniesienia” Innego, Drugiego w filozofii Hegla, utożsamienia go z Bogiem ${ }^{35}$.

Charakterystyczne także, podkreśla Leo Strauss, że droga racjonalizmu Cohena to jednocześnie droga do Boga i człowieka ${ }^{36}$. To szlak wiodaccy nie do abstrakcyjnego Boga filozofów, ale do żywego Boga, do Jahwe z Biblii i do człowieka Biblii, Tory i judaizmu.

Warto przy tym zauważyć, że w ten sposób Cohen stanął na stanowisku bliskim stanowisku innego wielkiego żydowskiego teologa tych czasów Leo Baecka,

32 W. Hanuszkiewicz, Filozofia Hermanna Cohena w perspektywie sporu o jedność metody transcendentalnej. Warszawa 2011, s. 30.

33 Ibidem.

${ }^{34}$ Por. T. Gadacz, Filozofia dialogu, [w:] Historia filozofii XX wieku. Nurty, t. 2. Neokantyzm, filozofia egzystencji, filozofia dialogu, Kraków 2009, s. 504.

35 Z.A. Sokuler, Gierman Kogien i fitosofija dialoga..., s. 60.

${ }^{36}$ L. Strauss, Pisma żydowskie Hermanna Cohena, tłum. A. Serafin, „Kronos” 2 (2012), s. 2. 
który już w polemice z Adolfem Harnackiem (Das Wesen des Christentums, 1900) w swojej pracy Das Wesen des Judentums (1905) wskazywał na to, że judaizm to nie idea, lecz tajemnica, to życie. I dla Cohena istotą objawienia biblijnego i judaizmu jest dialog. Objawienie zakłada bowiem Objawiającego i Tego, komu się objawia. W tym sensie Objawienie zakłada dialogiczne Ja i Ty. Idea ta została następnie rozwinięta w pracy Martina Bubera Ja $i$ Ty (Ich und Du), będaccej odpowiedzią na pracę Cohena z filozofii religii.

Ujawnia się tutaj zarazem specyficzna różnica w podejściu obu filozofów do dziedzictwa judaizmu. Mianowicie, podczas kiedy Cohen, podkreślając „czystość” żydowskiego monoteizmu, upatruje jednocześnie wartości judaizmu w jego racjonalności i zgodności z filozofią, Buber ceni bardziej „heterodoksyjne”, mistyczne elementy religijności Żydów, zwłaszcza wschodnio-europejskiego chasydyzmu ${ }^{37}$.

Cohen we Wprowadzeniu do pracy Religion der Vernunft aus den Quellen des Judentums, pytając o źródło oraz treść nauki (Wissenschaft) oraz religii (Religion), powiada wprost, że źródłem religii jest rozum. „Nie ma sprzeczności między rozsądkiem a rozumem" (Es gibt keinen Widerspruch gegen Verstand und Vernun$f t)^{38}$, pomiędzy rozumem religijnym a rozumem filozoficznym, rozumem religijnym a rozumem moralnym. Dotyczy to także judaizmu, którego treść, jak pisze, została co prawda wyrażona na kartach Biblii na sposób „literacki”, lecz jej istota jest racjonalna i filozoficzna. Nie jest wprawdzie, jak stwierdza, możliwa jedna religia, tak jak możliwa jest ,jedna matematyka” (Es gibt nur eine Mathematik, aber es gibt viele Religionen $)^{39}$, lecz od historycznej koncepcji judaizmu do filozofii religii wiedzie „prosta ścieżka”, a religia mojżeszowa na tej drodze nie jest jakimś „brakiem” (Mangel) w „religii rozumu” czy rodzajem jego „zastępnika” (Ersatz), lecz stanowi jego konieczny etap. Podkreślając, że żaden lud nie stworzył czystej „religii rozumu” i każda religia ma swój udział w tym procesie, Cohen podkreśla

37 Trafnie zatem pisze współczesny badacz: „Czystość monoteizmu, którą jeszcze w 1918 Hermann Cohen w Die Religion der Vernunft aus den Quellen des Judentums traktował jako wyróżniający rys tradycji żydowskiej, zostaje tu świadomie wyeliminowana. Ta dominująca od czasów Mendelssohna w niemieckim żydostwie doktryna jest dla Bubera, jak napisze on w późniejszej rozprawie, niczym innym jak »marnym Homunkulusem «, wytworem »rabinizmu «. Na jego miejscu umieszcza on chasydzkie legendy, będące dlań »wyrazem pełni żydowskiego jestestwa «. Tym samym przyznaje on żydostwu znaczenie, jakie w kulturowej świadomości Zachodu posiada grecka kolebka mitycznych opowieści. Wedle Bubera Żydzi są lepszymi Grekami — »być może jedynym narodem, który nigdy nie przestał tworzyć mitów «. Buberowska samoprezentacja dokonuje się w zadaniu: »Moja opowieść stoi na ziemi żydowskiego mitu a ponad nią rozpościera się niebo żydowskiego mitu «". B. Witte, Odrodzenie judaizmu z ducha nowoczesności — Martin Buber, [w:] idem, Żydowska tradycja i literacka nowoczesność. Heine, Buber, Kafka, Benjamin, tłum. R. Kubicki, A. Malitowska, Warszawa 2012, s. 164.

38 „Es gibt keinen Widerspruch gegen Verstand und Vernunft, keinen Widerspruch gegen menschliche Sittlichkeit im weitesten Umfang, der nicht zum Schwerpunkt einer angeblichen Religion würde". H. Cohen, Einleitung, [w:] idem, Religion der Vernunft aus den Quellen des Judentums. Eine jüdische Religionsphilosophie. Mit einer Einführung von Ulrich Oelschläger: Marixverlag, s. 30,https://www.

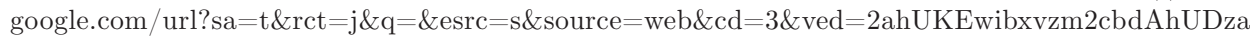
QKHVVhBwUQFjACegQICBAC\&url=http\%3A\%2F\%2Fwww.verlagshaus-roemerweg.de\%2Feshop\%2FLeseproben\%2F00241.pdf\&usg=AOvVaw2QHgbmF5r8hGR-BetRrtjY (dostęp: 15.09.2018).

${ }^{39}$ Ibidem. 
jednocześnie, że rola judaizmu jako „religii rozumu” jest jednak wyjątkowa i niepowtarzalna, tak ze względu na swój racjonalizm, jak i jej dialogiczny fundament, którego nie sposób odnaleźć w innych religiach.

Warto przy tym zwrócić uwagę na to, że Cohen swoją dialogiczną ideę przedstawił w pracy Religion der Vernunft aus den Quellen des Judentums (1919), ale Rosenzweig pisze, że zasady „nowego myślenia” po raz pierwszy zostały zarysowane już w Zasadach filozofii przyszłości Ludwiga A. Feuerbacha ${ }^{40}$, którego słusznie uważa się za prekursora filozofii dialogu XIX wieku. Zasadę dialogiczną ponownie ożywił Cohen, ale jak zauważa Rosenzweig, nie do końca uświadamiał on sobie znaczenie tego kroku w dalszym rozwoju filozofii i powstaniu „nowego myślenia"41. „Nowe myślenie”, jak pisze Rosenzweig, w odróżnieniu od „starego myślenia” Hegla i niemieckiego idealizmu jest myśleniem, które nie jest „logiczne”, lecz „gramatyczne”. To ,myślenie mowy"42.

Jeśli zapytać na czym polega przełomowe znaczenie dzieła pracy Religion der Vernunft aus den Quellen des Judentums, to niezależnie od jego walorów dialogicznych należy stwierdzić, że leży ono w jego rewolucyjnym w świecie europejskim — zwłaszcza w kontekście krytyki judaizmu w tradycji niemieckiej (poczynając od Marcina Lutra), jak i żydowskiej (na przykład Baruch Spinoza) — spojrzeniu na fenomen judaizmu. Cohen dowodzi w nim, że największe idee filozoficzne, którymi szczyci się Europa, w tym idea uniwersalnej ludzkości, nie pochodzą od Platona ani Arystotelesa, lecz od żydowskich proroków ${ }^{43}$.

Teza ta dotyczy jego zdaniem także uniwersalnego prawa moralnego. Wedle berlińskiego filozofa prawo moralne to istota Objawienia ${ }^{44}$. Podobnie jak Majmonides, Cohen twierdzi, że nie jest możliwy konflikt między prawem boskim oraz prawem, jakie narzuca sobie ludzki rozum ${ }^{45}$. Dlatego też jako uczeń Kanta Cohen nie mówi o Bogu, ale o naszej ,idei” absolutnego bytu ${ }^{46}$. Twierdząc, że cel ludzkości leży poza granicami skończoności i zakłada nieskończony proces doskonalenia się ludzkiej jednostki, jak pisze, Kant nie pomylił się co do realnej różnicy między realnym a idealnym. W tym sensie ideał Kanta i idea mesjanizmu Cohena są z sobą zbieżne. Cele ludzkości i cel mesjanizmu nie mają końca. Innymi słowy, na Ziemi nigdy nie nastanie era mesjańska, ale zawsze będzie trwał proces jej tworzenia ${ }^{47}$. Między realnym a idealnym rozwiera się przepaść.

\footnotetext{
${ }^{40}$ F. Rosenzweig, Kilka uwag ex post do..., s. 670.

41 Ibidem, s. 676.

42 Por. A. Żak, „Myślenie mowy” jako nowy racjonalizm Franza Rosenzweiga, [w:] Rozum $i$ słowo. Eseje dialogiczne, B. Baran, T. Gadacz, J. Tischner (red.), Kraków 1988.

${ }^{43}$ K. Seeskin, Neokantyzm żydowski: Hermann Cohen, tłum. P. Sajdek, [w:] D.H. Frank, O. Leaman, Historia filozofii żydowskiej, Kraków 2009, s. 812.

44 Ibidem, s. 818.

45 Ibidem, s. 819.

46 Ibidem, s. 822

47 Ibidem, s. 823 .
} 


\section{Stwórca i Pan świata czy abstrakcyjna zasada filozofów?}

Historycy filozofii, jak zwykli to czynić, mówiąc o poglądach Cohena, starają się przede wszystkim zachować logikę i treść jego myśli — Rosenzweig zachował jego ducha. Wyraża się to również w odniesieniu obu myślicieli do problemu Boga.

Wydarzenie, które mamy teraz na uwadze i przywodzimy za polskim badaczem $^{48,}$ znakomicie ilustruje różnicę między Bogiem Cohena i Rosenzweiga, biblijnym „Bogiem Abrahama, Izaaka i Jakuba” oraz „Bogiem filozofów”. Między Bogiem, z którym można wejść w dialogiczną i personalną relację, do którego, można zwrócić się słowem „Ty" a Bogiem, abstrakcyjną zasadą filozofów. Bogiem arche jońskich filozofów przyrody, bogiem „onto-logiki”, której panowanie — „od Jonii do Jeny" - wyznaczał Rosenzweig, bogiem-absolutem niemieckiego idealizmu itd.

Jak pisze polski badacz, Rosenzweig wspomina, że tematem ostatniego pożegnalnego wykładu Cohena w Marburgu było „pojęcie Boga” jako gwaranta wieczności świata i warunku możliwości wszelkiej moralności apodyktycznie dyktowanej przez rozum człowieka ${ }^{49}$. Po tym znakomitym wykładzie, jak czytamy, podszedł do Cohena wschodnio-europejski prosty Żyd i „łamaną niemczyzną” przyznał, że niewiele wprawdzie zrozumiał z wykładu, ale mimo to chciałby zadać jedno pytanie: „Profesorze, tyle pan mówi o Bogu, lecz gdzie w tym wszystkim jest Ribono Szel Olam, Stwórca i Pan świata?" 50.

Słysząc te słowa, tradycyjnie wychowany „syn kantora”, pokornie opuścił głowę

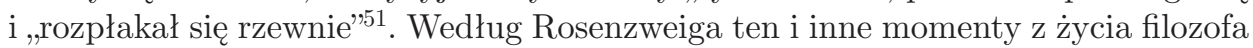
wyraźnie wskazują na stopniowe wycofywanie się Cohena z pozycji idealistycznego racjonalizmu i powrót do religijnego egzystencjalizmu.

Na fundamentalne dla Rosenzweiga pytanie o stosunek rozumu do objawienia, o stosunek Boga do człowieka i świata w swojej ,religii rozumu” Cohen odpowiada zatem, że Bóg jest radykalnie odmienny od świata. Bóg jest niezmienny, a świat jest sferą nieustannego przemijania. Stosunek Boga do świata to nie emanacja ani panteizm, lecz boska kreacja, stworzenie.

Jednakże w stworzonym świecie wyróżnia się, zdaniem Cohena, jeden szczególny element - istota Boga objawia się tylko w jego stosunku do człowieka. Cohen nazywa to ,korelacją"52. Człowiek jest „skorelowany” z Bogiem moca rozumu, jest istotą rozumną i jednocześnie moralną, taką, która może podejmować moralne wybory. Cohenowska „korelacja” to zarazem synonim i kryptonim „objawienia”, które oczyszczone z mitycznego ,przebrania” w istocie okazuje się stwarzaniem przez Boga warunków racjonalności człowieka, jego praktycznej moralności.

„Korelatem” Boga w Objawieniu nie jest zatem historyczny Mojżesz, lecz człowiek jako istota rozumna. Cohen to jak Mojżesz Mendelssohn — wierzący racjo-

\footnotetext{
${ }^{48}$ Por. A. Serafin, Cohen - Rosenzweig - Heidegger..., s. 164-165.

49 Ibidem, s. 165.

${ }^{50}$ Ibidem.

51 Ibidem.

52 Z.A. Sokuler, Gierman Kogien i fiłosofija dialoga..., s. 108. W prezentacji filozofii religii kierujemy się głównie tą pracą.
} 
nalista, wedle niego, rozum i wiara nie są sobie przeciwstawne, ale idą ręka w rękę i wzajemnie się wspierają. Cohen, pisze rosyjska badaczka Zinaïda Sokuler, „był przekonany o harmonii wiary i rozumu do tego stopnia, że z jego punktu widzenia, prawdziwa religia, nie może nie być religia rozumu"53. Filozof idzie tutaj wyraźnie w ślady Mendelssohna, który był człowiekiem głębokiej wiary, a jednocześnie, zgodnie z formułą Kanta „miał odwage posługiwać się własnym rozumem”54.

Z pojęciem „korelacji” nasz filozof łączy pojęcie „świętości”, której przedmiot, według niego, nie jest niczym innym jak sferą moralności. Berliński filozof, podążając za tezami filozofii religii Kanta i jego teorią moralną, zaprzecza zarazem możliwości ,świętości” innej niż moralna, czyli „świętości” przedmiotów, obrazów itp. W jego mniemaniu świat nie jest ani święty, ani boski, a jedyna możliwa „świętość" wyraża się w odniesieniu człowieka do drugiego człowieka, w moralności.

Wyrażając tę kwestię w terminologii biblijnej, Cohen chce powiedzieć, że związek człowieka z Bogiem polega na moralnym działaniu, które polega na „duchu świętości", Ruach-ha-Kodesz. W ten sposób poprzez objawienie, czyli podejmowanie moralnych decyzji, inny człowiek z „człowieka obok”, z Nebenmensch ${ }^{55}$, staje się „człowiekiem” w pełnym znaczeniu tego słowa, staje się Mitmensch. Z obcego staje się bliźnim i tylko wtedy, mówi Cohen, „On” może stać się „Ty”. Tym samym człowiek, jako ktoś stojący obok mnie, staje się dopiero „człowiekiem” we właściwym znaczeniu tego słowa, staje się moim bliźnim, bez którego „Ja” nie istnieje.

Według Cohena istnieje fundamentalna różnica między Ja i Ty i tę różnicę pozwala zidentyfikować jedynie religia. Przy czym, co przywodzi na myśl dialogikę Lévinasa, nie ma tu mowy o etycznej symetrii. I tak jak indywidualność bliźniego wobec mnie wyróżnia się cierpieniem, na które jedyną reakcją może być moje miłosierdzie, moją własną indywidualność wyróżnia grzech, który zawsze jest tylko mój, a nigdy Innego, Drugiego. Ja jest możliwe tylko dzięki Ty i to dzięki odkryciu dialogicznej relacji Ja do Ty możliwe jest tworzenie „własnej indywidualności”56. Tylko poprzez otwarcie „Ty” — mówi Cohen — mogę odkryć i poznać swoje „Ja"57.

Budując swoją dialogikę i swoją teorię religii w "granicach samego rozumu", Cohen pokazuje jednocześnie, że kochać Drugiego, Innego jest jednocześnie postępowaniem i racjonalnym i etycznym, zgodnym z nakazem sumienia, etyki i przykazania miłości bliźniego. Miłować Drugiego to bowiem kochać siebie samego, dlatego że „Inny” to „Ja Sam”.

Zdaniem Cohena „istotę objawienia” stanowi prawo moralne ${ }^{58}$. Niemniej trzeba tu zauważyć, że jego „religia rozumu” przewyższa treść moralnej doktryny Kanta, w którego moralnej koncepcji nie istnieje różnica między Ja i Ty, dlatego że każdy człowiek jako jednostka jest przedstawicielem uniwersalnej ludzkości. Tym samym, ukazując różnicę, a zarazem nierozerwalny związek między Ja i Ty, Cohen nie tylko podnosił doktrynę moralną Kanta na wyższy stopień, lecz ją w sensie istotnym

\footnotetext{
53 Ibidem, s. 71.

54 Ibidem, s. 81.

55 Ibidem, s. 116.

56 Ibidem.

57 Ibidem, s. 98.

${ }^{58}$ K. Seeskin, Neokantyzm żydowski: Hermann Cohen..., s. 818.
} 
przekraczał, stając się odkrywcą relacji Ja-Ty jako podstawy etyki oraz filozofii dialogu, tematu doprowadzonego następnie przez Rosenzweiga, Bubera i Lévinasa do niezwyklej myślowej subtelności.

\section{Cohen jako nauczyciel narodu niemieckiego}

Rozpoczynając swoje berlińskie wykłady, Cohen nie tylko rozwijał podjętą już w Marburgu refleksję nad projektem dialogicznej filozofii religii, lecz także refleksję w zakresie filozofii kultury i historiozofii. W wykładzie Was einigt die Konfessionen?, który miał miejsce latem 1917 roku na zebraniu Żydowskiego Wolnego Towarzystwa Naukowego (Freie Wissenschaftliche Vereinigung) ${ }^{59}$, podejmował pytania, których waga i znaczenie stały się czytelne dopiero w kontekście historii Niemiec i historii Europy XX wieku, a dokładniej w konfrontacji z totalitarnymi ideologiami i wydarzeniami dwudziestego stulecia.

W tej działalności Cohen pozostał wierny z jednej strony wychowawczej tradycji oświecenia i swoich europejskich mistrzów, z drugiej — tradycji judaistycznej. Wśród europejskich filozofów mamy tu na myśli przede wszystkim Kanta, z judaistycznej - Mojżesza Mendelssohna. Pozostając wiernym uczniem Kanta, Cohen ostro krytykował nacjonalistyczny nurt niemieckiej filozofii romantycznej, a także indywidualistyczną interpretację moralnej teorii Kanta, przede wszystkim w rozumieniu Johanna Gottlieba Fichtego. Będąc zwolennikiem oświecenia, nie występował bynajmniej przeciwko niemieckiemu romantyzmowi jako takiemu, poddawał jedynie krytyce skrajne volkistowskie i indywidualistyczne, „mistyczno-romantyczne" nurty ${ }^{60}$ „niemieckiej ideologii”,61, prowadzącej wprost do faszyzmu ${ }^{62}$. Majacc na uwadze całość jego poglądów, można powiedzieć, że był zwolennikiem tezy o jedności niemieckiego humanizmu, humanizmu takich przedstawicieli niemieckiego oświecenia, jak Lessing i Herder, jak też humanizmu niemieckich romantyków Goethego i Schillera.

Głównej jego zasługi w historii filozofii zwykło upatrywać się w tym, że twórczo rozwinął epistemologiczną, etyczną i estetyczną teorię Kanta, ale dla zrozumienia ideowej ewolucji niemieckiej historii, a zwłaszcza jej nazistowskiego etapu, szczególnie ważne wydaje się co innego — zastosowanie teorii etycznej Kanta do krytycznej analizy niemieckiej filozofii narodu i państwa.

Przypomnijmy tu, że jak pisał ostatni przedstawiciel neokantyzmu marburskiego, a jednocześnie student Cohena Ernst Cassirer, kultura i cywilizacja wciąż pozostają pod groźbą uśpionych, nieświadomych i destruktywnych mitów, z których w XX wieku jednym z najbardziej przerażających stał się „mit państwa" ${ }^{2}$ — symbol powrotu i zwycięstwa mythos nad logos, Natury nad Kulturą.

\footnotetext{
${ }^{59}$ Z.A. Sokuler, Gierman Kogien i fitosofija dialoga..., s. 78.

60 Ibidem, s. 80.

${ }^{61}$ G.L. Mosse, Kryzys ideologii niemieckiej. Rodowód intelektualny Trzeciej Rzeszy, tłum. T. Evert, Warszawa 1972 .

62 Z.A. Sokuler, Gierman Kogien i fitosofija dialoga, s. 80.

63 Por. E. Cassirer. Mit państwa, tłum. A. Staniewska, Warszawa 2006.
} 
W tym duchu w jednym ze swoich wykładów Theodor W. Adorno, bogatszy doświadczeniem totalitaryzmu ubiegłego wieku, demaskator wszelkich totalitarnych mitologii ,natury” i „ludu” (Volk) ${ }^{64}$, których kontynuacją stała się ideologia faszystowskiego totalitaryzmu, mówi, mając na uwadze XX wiek i faszyzm, że „klęska kultury nie stanowi bynajmniej dla myślenia przepustki do natury”65. Pisząc te słowa, jednocześnie zaznaczał, że filozofia nie wyrasta bynajmniej na glebie Natury, ale ,sama jest cząstką kultury, jest spleciona z kulturą̧"

Jak później Cassirer i Adorno, Cohen utrzymywał, że granica między człowieczeństwem i barbarzyństwem jest bardzo chwiejna i nietrwała, a odrzucenie rozumu równa się negacji człowieka. $\mathrm{W}$ tym sensie, jak słusznie zauważa współczesna rosyjska badaczka, jego ideowe analizy w XX wieku okazały się niezwykle przenikliwe i prorocze. Żydowski filozof rozumiał doskonale, jak głęboko destrukcyjny potencjał zawiera romantyczna filozofia narodu (Volk) oraz występująca w zarodku w XIX wieku ideologia „krwi i ziemi” (Blut und Boden), osiągające swój szczyt w ideologii nazistowskiej XX wieku.

Podkreślając wkład Cohena w wychowanie narodu niemieckiego, Sokuler zwraca jednocześnie uwagę na to, że chociaż chciał on mieć wpływ na „niemiecką ideologię", pozostał w swoich wysiłkach tylko niemym świadkiem przyszłych i nadchodzących z żelazną i nieubłaganą logiką wydarzeń historycznych. Tutaj okazał się on nie tylko racjonalnym analitykiem, lecz wprost „prorokiem”67. Jak podkreśla rosyjska badaczka, pragnął on dialogu Żydów i Niemców, ale zamiast dialogu nadeszła „katastrofa”"68. Dziś, z punktu widzenia totalitarnych doświadczeń XX wieku, można tylko ubolewać nad tym, że niemiecka historia wybrała sobie innych nauczycieli niż filozofowie epoki oświecenia, niż Kant, Lessing, Mendelssohn i przedstawiciele niemieckiego uniwersalnego humanizmu Herder, Goethe, Schiller, i wreszcie sam Cohen.

Dodajmy, że Cohenowi dane było tylko przewidzieć, ale nie wpływać na dziejowe konsekwencje volkistowskich teorii i ideologii. Zmarł dokładnie 100 lat temu, w 1918 roku (artykuł był pisany w roku 2018), jego żona Marta Lewandowski Cohen przeżyła go o kilkadziesiąt lat i zmarła w 1942 roku w obozie koncentracyjnym Teresienstadt w Czechach ${ }^{69}$. Ale testament Cohena, który już w czasie swego życia wyraźnie słyszał odgłosy nadchodzącej i nieuniknionej katastrofy, pozostaje aktualny do dziś, a jego koncepcja, która mówi, by kochać „Innego”, bo jest to jednocześnie i etyczne, ludzkie, i racjonalne, czyni z niego filozofa naszych czasów. $\mathrm{W}$ istocie bowiem Cohen pokazuje nam, że miłować „Innego” to czyn w pełni ludzki, czyli i racjonalny, i moralny zarazem. To zarazem wybór Siebie, dlatego że Inny to Ja Sam.

${ }^{64}$ K.R. Popper, Społeczeństwo otwarte i jego wrogowie, t. 2, tłum. H. Krahelska, Warszawa 1993, s. $61 \mathrm{n}$

65 T.W. Adorno, Umieranie dzisiaj, tłum. P. Graczyk, „Kronos” 3 (2012), s. 16.

${ }^{66}$ Ibidem. Zob. J. Krasicki, Człowiek, czyli Kultura, [w:] Aisthesis i Ratio. Człowiek w przestrzeni kultury $i$ estetyki, J. Krasicki, T. Akindynowa, Z. Pietrzak (red.), Wrocław 2014, s. 15.

67 Z.A. Sokuler, Gierman Kogien i fitosofija dialoga, s. 81.

68 Ibidem, s. 96.

69 T. Gadacz, Hermann Cohen (1842-1918), [w:] idem, Historia filozofii XX wieku. Nurty..., s. 514. 
Przesłanie to jest zgodne z przesłaniem Lévinasa, wedle którego Inny, Drugi, jak pisał, jest we mnie „wcześniej, niż spotkanie z nim”. „Mesjasz — powiada Lévinas - to sprawiedliwy, który cierpi, który wziął na siebie cierpienie innych. Któż ostatecznie bierze na siebie cierpienie innych, jeśli nie istota, która mówi »Ja«. Fakt nieuchylania się przed ciężarem, jaki narzuca cierpienie innych, określa samą ipseitas. Wszystkie osoby są Mesjaszami"70.

Oznacza to i dla Cohena, i dla Lévinasa, iż to odpowiedzialność za Innego, Drugiego czyni mnie dopiero podmiotem. Inny, Drugi nie istnieje dlatego, że Ja istnieję. Odwrotnie — ponieważ istnieje Inny, Drugi, „Ja jestem”.

\section{8. „Jakiego rozumu potrzebujemy dzisiaj?". Triumf i upadek ,czystego rozumu"}

Jak dzisiaj, na progu nowego tysiąclecia, po tragicznych wydarzeniach minionego wieku, po „złu epoki”"71, patrzeć na humanistyczną wiarę w „czysty rozum” Kanta, Cohena i innych idealistycznych myślicieli? Czy można ją jeszcze podzielać? Czy i w jakiej mierze można jeszcze podzielać przekonania współczesnych obrońców dziedzictwa oświecenia takich jak Jürgen Habermas? Czy, mówiąc inaczej, jak zapytujemy w innym miejscu: „Jakiego rozumu potrzebujemy dzisiaj?”72.

Mając na uwadze te pytania, pamiętamy, że Cohen tak jak w swoich pismach, tak też głosząc swoje berlińskie wykłady, nie podzielał wiary w żaden „narodowy” rozum, rozum „niemiecki” lub ,żydowski” — co, jak się później okazało, nie było wcale oczywiste na przykład dla Heideggera $(\text { Czarne zeszyty })^{73}$ — ale jak Platon, Kant i Husserl wierzył w jeden uniwersalny rozum ludzki. Szukał jego obecności w równym stopniu na kartach Biblii, u żydowskich proroków, u greckich filozofów, u średniowiecznych racjonalistów, u Majmonidesa, w irenistycznej teorii religii Mikołaja z Kuzy ${ }^{74}$ (w jego dialogu De pace fidei) i tego rozumu, jak umiał, bronił. Jak Husserl bronił go przed irracjonalizmem i siłą destrukcyjnych mitów: państwa, narodu, ziemi itd. Podobieństwo to można rozszerzyć. Cohen, podobnie jak Husserl, bronił rozumu i jak autorowi Idei nie dane mu było doświadczyć jego Upadku. Przypomnijmy też, że podobnie jak Husserlowi, który umarł w 1938 roku i którego co prawda dotknęły prześladowania z powodu jego żydowskiego pochodzenia, dane było nie dożyć wybuchu drugiej wojny światowej i Holokaustu, także Cohenowi dane było nie dożyć „,zasu pogardy”. Dożył w spokoju końca swoich dni jako akademicki uczony w mieszczańskim Berlinie, w mieście, które niewiele później stało się symbolem nazizmu i triumfu ,nierozumu” naszej epoki ${ }^{75}$.

${ }^{70}$ E. Lévinas, Trudna wolność. Eseje o judaizmie, tłum. A. Kuryś, Gdynia 1991, s. 93.

71 J. Krasicki, Zło epoki, [w:] idem, Przeciw nicości. Eseje, Kraków 2002, s. 85-95.

72 Zob. J. Krasicki, Kakoj razum nam nużen siegodnia?, [w:] Rationalism in the Epoch of Unreason, J. Krasicki, T. Akindinova (eds.), Wrocław 2012.

73 Zob. np. P. Trawny, Heidegger $i$ mit spisku żydowskiego, tłum. W. Wawrocki, Warszawa 2017.

${ }^{74}$ Z.A. Sokuler, Gierman Kogien i fiłosofija dialoga, s. 82. Tę postawę wobec religii Cohena podzielał Rosenzweig, który pisał: „Bóg nie stworzył religii, ale świat”. F. Rosenzweig, Kilka uwag ex post..., s. 679 .

75 Zob. Rationalism in the Epoch of Unreason... 
Dziś, po totalitarnych doświadczeniach XX wieku, po Holokauście, po wydarzeniach „Kołymy i Oświęcimia” (J. Tischner), na progu XXI wieku jest nam bardzo trudno podzielić tę wiarę. Wiarę twórców oświecenia, wiarę Kanta, Cohena i Husserla. Po doświadczeniach XX wieku termin „czysty rozum” budzi w nas skojarzenia nie z „czystością rozumu” i ludzkiego poznania, lecz bardziej z „czystością rasy”, „krwi i ziemi”. Po totalitarnych doświadczeniach XX wieku, po Holokauście, wiemy, że rozum może dużo i w dobrym, i w złym, że nie istnieje rozum „poza dobrem i złem”76, poza „różnicą aksjologiczną” (E. Lévinas). Co więcej, wiemy, że nadal można podzielać oświeceniową i racjonalistyczną wiarę w rozum, ale wiemy zarazem, że nie da się dzisiaj filozofować poza doświadczeniem historycznym XX wieku, bo jak powiada Józef Tischner „Oświęcim był i była Kołyma”. „Rozum i zło to — jak piszemy w innym miejscu - chyba najbardziej splątany węzeł nowożytnej historii intelektualnej"77, ,splątany” niemniej rzeczywisty i nie da się go „rozwiązać” jednym aktem, tak jak uczynił to na przykład Aleksander Macedoński wobec „węzła gordyjskiego". Jednym słowem, aby zwrócić się do teologicznej frazy, dziś nie wierzymy w żaden „niepokalanie poczęty” w tym tė̇ filozoficzny „,czysty rozum”.

Naszym zdaniem ludzki rozum ma zawsze podwójne, czyli Janusowe, oblicze; oblicze jasne oraz ciemne. Tego drugiego, „ciemnego”, Cohenowi i Husserlowi na szczęście nie dane było doświadczyć. I jeden, i drugi żyli w czasach — jeśli tak się wyrazić — „rajskiej niewiedzy” o nadchodzącym złu, w dobie triumfu „czystego rozumu", przed jego totalnym Upadkiem. Nie było im dane dożyć czasów jego upadłości. Dlatego ich stosunek do rozumu, a dokładniej ich wiara w jeden uniwersalny rozum ludzki jest całkowicie inna niż na przykład dotkniętego doświadczeniem Holokaustu Lévinasa ${ }^{78}$, który pisał wprost, że zalążki patologii tkwiły w samej europejskiej kulturze filozoficznej jako dominacji „Toż-samego"79 nad Innym, w lęku przed Innością, w ,immanencji myśli”"80, w panowaniu ,kultury immanencji”81, a ta myślowa oraz cywilizacyjna i kulturowa konstelacja rozciągała swoje panowanie nad Europą przez dwa tysiąclecia — od swych jońskich greckich początków po nowożytność i Hegla (von Ionien bis Jena — Rosenzweig) — niosąc w sobie totalitarny potencjał ${ }^{82}$, owocujący w totalitarnych ideologiach ubiegłego stulecia.

${ }^{76}$ J. Krasicki, Kakoj razum nam nużen siegodnia, s. 258-259.

77 Zob. J. Krasicki, Rozum i zło (zamiast Wstępu), [w:] idem, Przeciw nicości, s. 10-13.

${ }^{78}$ Z.A. Sokuler, Gierman Kogien i fitosofija dialoga, s. 200 n. Zob. także E. Lévinas, Trudna wolność. Eseje o judaizmie, passim; T. Gadacz, Samotność po Auschwitz, „Znak” 4 (1991); M. Kozak Problem zła w filozofii Emmanuela Lévinasa, Kraków 2011, s. 81-130.

${ }^{79}$ Por. E. Lévinas, Całość i nieskończoność. Esej o zewnętrzności, tłum. M. Kowalska, Warszawa 2002, s. 4 n.

80 Ibidem, s. 8 n.

${ }^{81}$ Por. B. Skarga, Emmanuel Lévinas: kultura immanencji, „Studia Filozoficzne” 1984, nr 9.

82 Por. E. Lévinas, Całość i nieskończoność. Esej o zewnętrzności, passim. Jak pisze współczesna badaczka, „odnosząc się do ontologii Heideggera, francuski filozof także piętnuje przemoc, którą w jego przekonaniu — niesie ze sobą filozofia bytu i bycia: »Ontologia jako filozofia pierwsza jest filozofią mocy. Prowadzi do idei Państwa i całości wolnej od przemocy, ale nie może się ustrzec przemocy, jaką żyje ta wolność od przemocy i jaka przejawia się w tyranii państwa«". M. Kozak, Problem zła w filozofii Emmanuela Lévinasa, s. 129. 
Z właściwym sobie patosem i powagą wynikającą z rozpoznania „kryzysu”, w jakim znalazła się nauka i „duch” Zachodu, Husserl, jak Cohen, chciał „leczyć” schorzałą „ludzkość europejską” z jej duchowych chorób i boleści, z psychologizmu, naturalizmu, historyzmu, nacjonalizmu (sic!), sceptycyzmu w teorii poznania i etyce przy pomocy „czystego”, czyli transcendentalnego rozumu i transcendentalnej fenomenologii ${ }^{83}$, pozostając przy tym bliskim ideału ,filozofii naukowej” oraz krytycznego etycznego idealizmu Cohena, i w jednym, i w drugim wypadku zbudowanych na fundamencie filozofii jako ,nauki".

Owszem, filozofia jako „nauka” to — wedle autora Badań logicznych — ,historyczny ruch objawienia uniwersalnego rozumu »przyrodzonego «człowieczeństwu jako takiemu"84. W tym znaczeniu „rozum” filozoficzny stanowi właściwy sposób bycia Europejczykiem i może być tylko jeden, powszechny i uniwersalny. Na tym przekonaniu i na wierze w ów wszechwładny rozum zbudowano filary filozofii europejskiej i „europejskiego człowieczeństwa”. Jednak po totalitarnych doświadczeniach XX wieku, po doświadczeniu „Auschwitzu i Kołymy” jest to już dla nas wiara bezpowrotnie utracona, a jej źródła bezpowrotnie wyschły.

W tym momencie, aby strawestować przytoczone słowa Husserla, rodzi się zarazem pytanie o to, jaki to „uniwersalny rozum »przyrodzony« człowieczeństwu jako takiemu” „objawił się” „ludzkości europejskiej”85 i „człowiekowi europejskiemu” itd., na przykład w koncepcji „ostatecznego rozwiązania” (niem. Endlösung) w „kwestii żydowskiej”, którego to decyzja zapadła mocą spotkania w Wannsee ${ }^{86}$ ? Czy Cohen oraz Husserl, który jako „filozof” mienił się „funkcjonariuszem ludzkości"87 (w innych przekładach „urzędnikiem”), byliby w stanie wyobrazić sobie to, że z pomocą tego „uniwersalnego rozumu” ci sami przedstawiciele „ludzkości europejskiej”88 i „uniwersalnego rozumu”, których „europejski rozum” w pracy Kryzys europejskich nauk i transcendentalna fenomenologia (1935) Hus-

83 Jak pisze polski badacz, Husserl „w swoich rozważaniach etycznych posługiwał analogią między czystą etyką a czystą logiką, etycznym i logicznym idealizmem. Sceptycyzm w etyce jest równie absurdalny, jak psychologizm w logice i teorii poznania. W naukowej etyce możliwa jest eliminacja wszelkiej »przypadkowej względności«. »Tak samo prawda jest obiektywną prawdą płynącą z apriorycznych zasad prawa (Gesetzesgründen), tak i piękno, dobro, znamienitość, praktyczna powinność są wyznaczone dzięki apriorycznym zasadom prawa«". Z. Krasnodębski, Fenomenologia i tęsknota do wspólnoty, [w:] idem, Postmodernistyczne rozterki kultury, Warszawa 1996, s. 52.

${ }^{84}$ Por. E. Husserl, Powołanie filozofi, tłum. M. Skwieciński, [w:] Filozofia i socjologia XX wieku, t. 1, B. Baczko (red.), Warszawa 1965, s. 301 (fragment Kryzys nauk europejskich $i$ transcendentalna fenomenologia).

${ }^{85}$ E. Husserl, Kryzys nauk europejskich a fenomenologia transcendentalna, tłum. S. Walczewska, Kraków 1987, s. 1 n.

86 „Komendant Oświęcimia, Rudolf Hess zeznał, iż w lecie 1941 Himmler powiedział mu w cztery oczy, wyjątkowo bez obecności adiutanta, że »Führer« rozkazał mu ostateczne rozwiązanie kwestii żydowskiej. My — SS - mamy ten rozkaz zrealizować". Por. A. Niewiadomski, Geneza zbrodniczej decyzji, „Polityka” 1955, nr 38 z 23 XI 1995 (omówienie dwu prac na temat Holocaustu: G. Heisohn, Dlaczego Oświęcim - Plan Hitlera i bezradność potomnych; G. Aly, Ostateczne rozwiąanie. Przemieszczenie narodów $i$ mord na europejskich Żydach). Por. także M.R. Marrus, Holocaust, tłum. A. Tomaszewska, Warszawa 1993, s. 52-85; J. Krasicki, Zło epoki, s. 90.

87 E. Husserl, Powołanie filozofii..., s. 303.

88 E. Husserl, Kryzys nauk europejskich..., s. 1 n. 
serl tak wychwalał, w ciągu kilku lat po śmierci autora Idei (Husserl zmarł w 1938 roku) będą wysyłać do komór gazowych i palić w krematoriach jego siostry i braci (dwie siostry Husserla zginęły w obozach koncentracyjnych) ${ }^{89}$ ?

Pisaliśmy o ideowych i metodologicznych zbieżnościach nauki Cohena i Husserla. Jednocześnie należy jednak mieć na uwadze to, że ze względu na dialogizm nauki Cohena i monadologizm Husserla mają one w istocie wyraźnie zakreślone granice i są bardzo ograniczone. Jeśli patrzeć na ich dzieło z perspektywy dialogicznej, Cohen i Husserl wydają się stać na przeciwległych ideowych biegunach. Można powiedzieć, że Cohen dzięki swej dialogice i ortodoksyjnemu judaizmowi przekroczył granicę dla Husserla nieprzekraczalną. Nieprzekraczalną nawet mimo podejmowanych przez niego ciągłych prób, aby wyjść, jeśli tak powiedzieć, z zakreślonego przez siebie samego kręgu ,solipsyzmu wieloosobowego" (M. Merleau-Ponty $)^{90}$. Te próby to między innymi koncepcja „monadologicznej intersubiektywności” Husserla ${ }^{91}$, w której myślenie o Drugim, Innym staje się rodzajem transcendentalnej egologii, bez nadziei dotarcia do „Innego” jako „Innego” właśnie.

Koncepcja Innego, Drugiego Cohena wydaje się zatem stanowić przeciwieństwo transcendentalnego idealizmu Husserla, u którego „Inny” to jakby nie patrzeć, zawsze tylko ,anologon” mojego ja, to intencjonalny „przedmiot” mojej świadomości lub ,sens" konstytuowany przez świadomość transcendentalną.

W rezultacie swoją dialogiką Cohen wykroczył poza zaklęte „kredowe koło” transcendentalizmu i zarysował już radykalnie odmienne ,perspektywy człowieka” (R. Garaudy), które poszerzał Rosenzweig i inni dialogicy. Tak oto w filozofii Cohena, „choroba” krytycznego idealizmu i transcendentalizmu nie okazała się „,chorobą na śmierć”, jego „upadek” był ku „powstaniu”. Ku „powstaniu” rozumu i Człowieka.

\section{Przesłanie}

Totalitarne doświadczenia ubiegłego wieku doprowadziły do tego, że obecnie także za inspiracją dzieła Cohena coraz częściej szukamy identyfikacji człowieka poza zasada „onto-logiki”, a dzisiejszy odwrót od humanizmu i ruch w kierunku posthumanizmu występuje głównie z powodu strachu przed pogrzebaniem człowieka w logice myślowego „onto-logicznego” archipelagu, według Rosenzweiga, rozciągającego się „od Jonii do Jeny”. Od Parmenidesa i Heraklita do Hegla i Heideggera.

Winna jest temu, jak pokazali w swojej krytyce oświecenia tacy myśliciele jak Max Horheimer i Theodor W. Adorno, w krytyce doktryny Hegla - Franz Rosenzweig, w analizach nowoczesności - Zygmunt Bauman i Michel Foucault, filozofia skażona myślowym totalizmem i Filozofią Tożsamości ${ }^{92}$. To — jak powiedział Jó-

${ }^{89}$ Zob. także J. Krasicki, Powołanie filozofii, czyli co ludzie „prostego serca” mieliby do powiedzenia filozofii współczesnej?, „Studia Redemtorystowskie” 13, 2015, s. 9 n.

${ }^{90}$ Zob. R. Garaudy, Perspektywy człowieka. Egzystencjalizm, myśl katolicka, marksizm, tłum.

Z. Butkiewicz, Z. Rogoziński, Warszawa 1968, s. 43.

91 E. Husserl, Medytacje kartezjańskie, tłum. A. Wajs, Warszawa 1982, s. 130 n.

92 Zob. B. Skarga, Tożsamość i różnica. Eseje metafizyczne, Kraków 1997. 
zef Tischner — ,filozofie totalistyczne, dążące do tego, by objąć całość rzeczywistości za pomocą pojęcia bycia i pojęć jemu pochodnych, sprawiły że staliśmy się głusi i ślepi na twarz innego. Obowiązkiem filozofii jest uleczyć nas z tej ciasnoty"93.

Słowa te mają ciężar testamentu. Napisał je polski filozof, który jednocześnie zdawał sobie sprawę z tego, jak ogromny intelektualny dług zaciągnął u filozofów dialogików. I on, i inni polscy myśliciele, do których chciałby dołączyć również piszący te słowa, ten testament, jak potrafią, dziś starają się wypełnić.

\section{Bibliografia}

Adorno T.W., Umieranie dzisiaj, tłum. P. Graczyk, „Kronos” nr 3 (2012).

Agamben G., Idea nauki, [w:] idem, Idea prozy, tłum. E. Górniak Morgan, Warszawa 2018.

Biełow W.N., Fiłosofija rieligii Giermana Kogiena, [w:] Poznanije i rieligija. Epistiemołogija rieligioznogo opyta $w$ russkoj i jewriejskoj mysli, J. Dobieszewski, S. Krajewski, J. Mach (red.), Warszawa 2018.

Cassirer E., Mit państwa, tłum. A. Staniewska, Warszawa 2006.

Cohen H., Einleitung, [w:] idem, Religion der Vernunft aus den Quellen des Judentums. Eine jüdische Religionsphilosophie. Mit einer Einführung von Ulrich Oelschläger,

https: / $/$ www.google.com/url? sa $=$ t\&rct $=j \& q=\&$ esrc $=$ s\&source $=$ web\&cd $=3 \& v e d=2 \mathrm{a}$ hUKEwibxvzm2cbdAhUDzaQKHVVhBwUQFjACegQICBAC\&url=http $\% 3 \mathrm{~A} \% 2$ F\%2Fwww.verlagshaus-oemerweg.de\%2Feshop\%2FLeseproben\%2F00241.pdf\&us$\mathrm{g}=\mathrm{AOvVaw} 2 \mathrm{QHgbmF} 5 \mathrm{r} 8 \mathrm{hGR}-$ BetRrtjY (dostęp: 15.09.2018).

Ciszewski M., Cohen Hermann, [w:] Encyklopedia Katolicka, R. Łukaszyk, L. Bieńkowski, F. Gryglewicz (red.), t. 3, Lublin 1985.

Czardybon B., Rosyjski wariant kantyzmu i neokantyzmu, „Estetyka i Krytyka” 26 (3) 2012 (Postneokantyzm-ontologizm).

Damasio A., Bład Kartezjusza. Emocje, rozum i ludzki mózg, tłum. M. Karpiński, Poznań 2016.

Dmitrijewa N.A., Russkoje nieokantianstwo: „Marburg w Rossii”, Moskwa 2007.

Gadacz T., Filozofia dialogu, [w:] idem, Historia filozofii XX wieku. Nurty, t. 2. Neokantyzm, filozofia egzystencji, filozofia dialogu, Kraków 2009.

Gadacz T., Hermann Cohen (1842-1918), [w:] idem, Historia filozofii XX wieku. Nurty, t. 2. Neokantyzm. Filozofia egzystencji. Filozofia dialogu, Kraków 2009.

Gadacz T., Samotność po Auschwitz, „Znak” 1991, nr 4.

Garaudy R., Perspektywy człowieka. Egzystencjalizm, myśl katolicka, marksizm, tłum. Z. Butkiewicz, J. Rogoziński, Warszawa 1968.

Habermas J., Działanie komunikacyjne i rozum zdetranscendentalizowany, [w:] idem, Między naturalizmem a religia. Rozprawy filozoficzne, tłum. M. Pańkow, Warszawa 2012 .

Hanuszkiewicz W., Filozofia Hermanna Cohena w perspektywie sporu o jedność metody transcendentalnej, Warszawa 2011.

Heschel A.J., Prorocy, tłum. A. Gorzkowski, Kraków 2014.

93 J. Tischner, Filozofia dramatu, Kraków 1998, s. 31. 
Husserl E., Kryzys nauk europejskich a fenomenologia transcendentalna, tłum. S. Walczewska, Kraków 1987.

Husserl E., Medytacje kartezjańskie, tłum. A. Wajs, Warszawa 1982.

Husserl E., Powołanie filozofii, tłum. M. Skwieciński, [w:] Filozofia i socjologia XX wieku, B. Baczko (red.), Warszawa 1965, t. 1 (fragment Kryzys nauk europejskich i transcendentalna fenomenologia).

Kozak M., Problem zła w filozofii Emmanuela Lévinasa, Kraków 2011.

Krajnien K., Biełow W.N., Izuczenije nieokantianstwa: ukazanija k cztieniju, „Kantowski sbornik. Naucznyj żurnał" 2 (28) 2008.

Krasicki J., Bierdiajew a neokantyzm, [w:] idem, Bierdiajew i inni. W kręu myśli rosyjskiego renesansu religijno-filozoficznego, Warszawa 2012.

Krasicki J., Człowiek, czyli Kultura, [w:] Aisthesis i Ratio. Człowiek w przestrzeni kultury i estetyki, J. Krasicki, T. Akindynowa, Z. Pietrzak (red.), Wrocław 2014.

Krasicki J., Inny $i$ śmierć Innego $w$ filozofii G.W.F. Hegla i Franza Rosenzweiga, [w:] Bóg - człowiek — świat: szkice w myśli filozoficznej Franza Rosenzweiga, D. Jacyk-Manikowska (red.), Wrocław 2017. Krasicki J., Kakoj razum nam nużen siegodnia?, [w:] Rationalism in the Epoch of Unreason, J. Krasicki, T. Akindinova (eds.), Wrocław 2012.

Krasicki J., „Ot smierti, ot triepieta pieried smiertiu...” (Kogien - Rozienzwajg Chajdieggier), [w:] idem, Razum i Drugoj. Opyty po russkoj i jewropiejskoj mysli, Sankt-Pietierburg 2015.

Krasicki J., Powołanie filozofii, czyli co ludzie „prostego serca” mieliby do powiedzenia filozofii wspótczesnej?, „Studia Redemtorystowskie” 13, 2015.

Krasicki J., Rozum i zło (zamiast Wstępu), [w:] idem, Przeciw nicości. Eseje, Kraków 2002.

Krasicki J., Zło epoki, [w:] idem, Przeciw nicości. Eseje, Kraków 2002.

Krasnodębski Z., Fenomenologia i tęsknota do wspólnoty, [w:] idem, Postmodernistyczne rozterki kultury, Warszawa 1996.

Lévinas E., Całość i nieskończoność. Esej o zewnętrzności, tłum. M. Kowalska, Warszawa 2002.

Lévinas E., Trudna wolność. Eseje o judaizmie, tłum. A. Kuryś, Gdynia 1991.

Mosse G.L., Kryzys ideologii niemieckiej. Rodowód intelektualny Trzeciej Rzeszy, tłum. T. Evert, Warszawa 1972.

Niewiadomski A., Geneza zbrodniczej decyzji, „Polityka” 1955, nr 38.

Popper K.R., Społeczeństwo otwarte i jego wrogowie, t. 2, tłum. H. Krahelska, Warszawa 1993.

Rorty R., Przygodność, ironia, solidarność, tłum. W.J. Popowski, Warszawa 2009.

Rosenzweig F., Gwiazda zbawienia, tłum. T. Gadacz, Kraków 1998.

Rosenzweig F., Nowe myślenie. Kilka uwag ex post do Gwiazdy zbawienia, [w:] idem, Gwiazda zbawienia, tłum. T. Gadacz, Kraków 1998.

Rosenzweig F., Zmiana frontów, tłum. A. Serafin. „Kronos” 2012, nr 2.

Rozienzwajg F., Zwiozda izbawlenija, tłum. J. Jandutowoj, Moskwa 2017.

Scholem G., Żydzi i Niemcy, Eseje. Listy. Rozmowa, tłum. A. Zawanowska, A. Lipszyc, Sejny 2006.

Serafin A., Cohen - Rosenzweig - Heidegger. O zmianie frontu w Davos, „Estetyka i Krytyka" 26 (3) 2012 (Postneokantyzm-ontologizm). 
Skarga B., Emmanuel Lévinas: kultura immanencji, „Studia Filozoficzne” 1984, nr 9.

Skarga B., Tożsamość i różnica. Eseje metafizyczne, Kraków 1997.

Sokuler Z.A., Gierman Kogien i fitosofija dialoga, Moskwa 2008.

Sokuler Z.A., Gierman Kogien kak aktualnyj myslitiel. Razmyszlaja nad knigoj: Kogien G. Tieorija opyta Kanta,https://www.google.com/url?sa=t\&rct=j\&q=\&esrc=s\& source $=$ web $\& \mathrm{~cd}=4 \& \mathrm{cad}=$ rja\&uact $=8 \&$ ved $=2 \mathrm{ahUKEwiD} 84 \mathrm{zUqd} 3 \mathrm{cAhUHL} 1 \mathrm{AKH}$ STjCKQQFjADegQIBxAB\&url=http\%3A\%2F\%2Fplatona.net\%2Fload\%2Fzhurnaly_po_filosofii\%2Fvoprosy_filosofii\%2Fvoprosy_filosofii_2013_g_1\%2F78-1-0$-3942 \& u s g=$ AOvVaw2kZTURUhbJt_sv0hS-owA_(dostęp: 7.08.2018).

Strauss L., Pisma żydowskie Hermanna Cohena, tłum. A. Serafin, „Kronos” 2012, nr 2.

Tatarkiewicz W., Szkoła marburska i jej idealizm (w setna rocznicę marburskiej dysertacji Wtadysława Tatarkiewicza), P. Parszutowicz (red.), Kęty 2010.

Tischner J., Filozofia dramatu, Kraków 1998.

Trawny P., Heidegger i mit spisku żydowskiego, tłum. W. Wawrocki, Warszawa 2017.

Witte B., Odrodzenie judaizmu z ducha nowoczesności - Martin Buber, [w:] idem, Żydowska tradycja i literacka nowoczesność. Heine, Buber, Kafka, Benjamin, tłum. R. Kubicki, A. Malitowska, Warszawa 2012.

Żak A., „Myślenie mowy” jako nowy racjonalizm Franza Rosenzweiga, [w:] Rozum i słowo. Eseje dialogiczne, B. Baran, T. Gadacz, J. Tischner (red.), Kraków 1988. 